\title{
Sinergi antara Orang Tua dan Pendidik dalam Pendampingan Belajar Anak selama Pandemi Covid-19
}

\author{
Arini Dwi Cahyani ${ }^{1}{ }^{凶}$, Wiwin Yulianingsih ${ }^{1}$, MV. Roesminingsih ${ }^{1}$ \\ Pendidikan Luar Sekolah, Universitas Negeri Surabaya, Indonesia ${ }^{(1)}$ \\ DOI: $\underline{10.31004 / o b s e s i . v 6 i 2.1130}$
}

\begin{abstract}
Abstrak
Banyak orang tua beranggapan tanggung jawab pendidikan ada pada pendidik dimasa pandemi saat ini, sehingga orang tua tidak mau ikut bersinergi dengan pendidik. Tujuan dari penelitian ini, yaitu mendeskripsikan sinergi orang tua dengan pendidik di Kelompok Bermain (KB) Kuncup Harapan Kota Baru Driyorejo Gresik dalam mendampingi belajar anak selama masa pandemi Covid-19. Penelitian ini menggunakan pendekatan kualitatif deskriptif dengan subjek penelitian pendidik dan orang tua KB Kuncup Harapan. Teknik pengumpulan data menggunakan wawancara terstuktur dan dokumentasi. Teknik analisis data dengan Miles dan Hubermen. Hasil penelitian menunjukkan bahwa terdapat sinergi orang tua dengan pendidik KB Kuncup Harapan dalam pendampingan belajar anak usia dini. KB Kuncup Harapan memiliki program parenting, sebab peran orang tua sebagai demonstraktor, modelling, mentoring, organizing yang berkaitan dengan peran pendidik sebagai motivator, mediator, fasilitator dan evaluator. Bentuk kegiatan parenting KB Kuncup Harapan selama pandemi Covid-19, yaitu keterlibatan belajar di rumah, komunikasi, volunteer, dan pengambilan keputusan pendidikan anak.
\end{abstract}

Kata Kunci: peran orang tua; peran pendidik; sinergi, belajar dari rumah; Covid-19

\begin{abstract}
Many parents think the responsibility for education lies with educators during the current pandemic, so that parents do not want to collaborate with educators. The purpose of this research is to describe the synergy between parents and educators in the Kuncup Harapan Kota Baru Driyorejo Gresik Play Group in accompanying children's learning during the Covid-19 pandemic. This study used a descriptive qualitative approach with the research subjects of educators and parents of KB Kuncup Harapan. Data collection techniques using structured interviews and documentation. Data analysis techniques with Miles and Hubermen. The results showed that there was a synergy between parents and Kuncup Harapan KB educators in early childhood learning assistance. KB Kuncup Harapan has a parenting program, because the role of parents as demonstrators, modeling, mentoring, organizing is related to the role of educators as motivators, mediators, facilitators and evaluators. The form of Kuncup Harapan family planning parenting activities during the Covid-19 pandemic, namely the involvement of learning at home, communication, volunteering, and making children's education decisions.
\end{abstract}

Keywords: parent roles; teachers roles; synergy; learning from home; Covid-19

Copyright (c) 2021 Arini Dwi Cahyani, et. al.

$\triangle$ Corresponding author:

Email Address : arinidwicahyani24@gmail.com ( Surabaya, Indonesia )

Received 2 February 2021, Accepted 24 February 2021, Published 1 August 2021 


\section{PENDAHULUAN}

Awal tahun 2020 dunia mengalami musibah kesehatan secara global yang mengharuskan segala bentuk pelayanan publik termasuk pendidikan dibatasi dalam aktivitasnya. Keterbatasan ini diakibatkan karena terdapat penyakit mematikan, yaitu disebabkan oleh virus Corona atau servere acute respiratory sydnrome coronavirus 2 (SARS-CoV2) (Lai et al., 2020). Virus Corona ini dikenal dengan sebutan Covid-19. Penyebaran Covid-19 pertama yang berasal dari Wuhan, Provinsi Hubai China. Penyebaran cepat terjadi di seluruh dunia termasuk Indonesia, sehingga WHO (World Health Organization) secara resmi menetapkan Covid-19 sebagai pandemi pada tanggal 09 Maret 2020 (Satgas Covid-19, 2021). Penularan Covid-19 di Indonesia dari waktu ke waktu mengalami peningkatan, jumlah masyarakat Indonesia yang positif terinfeksi Covid-19 pada tanggal 04 Februari 2021, yaitu 1.123.105 orang (Satgas Covid-19, 2021). Dengan adanya pandemi Covid-19 yang merupakan bencana non-alam, sangat mengganggu aktivitas dan juga mengubah pola tatanan kehidupan manusia. Tentunya juga akan mempengaruhi proses belajar mengajar di sekolah. Anak usia sekolah selama pandemi Covid-19 pelaksanaan proses belajar mengajar dilakukan di rumah dengan memanfaatkan gadget atau gawai yang terhubung dengan internet yang menjadi alternatif agar tidak terjadi kontak fisik secara langsung. Hal ini dilakukan, sebab penularan Covid-19 dapat terjadi antar manusia maupun hewan (Yulianingsih et al., 2020). Maka dari itu selama belajar di rumah diperlukan pendampingan orang tua dalam proses belajar mengajar anak, sebagai pengganti peran pendidik di sekolah (Wardani, A., \& Ayriza, 2020).

Pada kondisi pandemi saat ini peranan keluarga menjadi pendukung utama dalam proses belajar anak. Pernyataan ini dapat diartikan bahwa pendidikan dikembalikan lagi kepada keluarga untuk diberikan kepercayaan dalam mendampingi proses belajar mengajar anak (Yulianingsih et al., 2020). Keluarga tidak dapat melepaskan begitu saja dalam mendidik anak, sebab keluarga adalah proses seumur hidup yang berlangsung sepanjang hayat, sehingga setiap individu memperoleh nilai, pengetahuan, sikap dan keterampilan yang berasal dari pengalaman yang didapatkan dipengaruhi oleh lingkungan termasuk keluarga, tetangga, tempat kerja, sekolah, tempat bermain dan media massa (Sudjana, 2004). Maka demikian, pendidikan pertama dan utama yang didapatkan manusia berasal dari keluarga (informal) (Wahy, 2012). Di dalam keluarga anak dibentuk berdasarkan kebiasaan yang dilakukan oleh anggota keluarga terutama orang tua. Disini anak diibaratkan kertas putih yang akan mendapatkan coretan sedemikian rupa berdasarkan bagaimana orang tua dalam mendidik dan lingkungan yang mempengaruhi (Muttakhidah, 2016). Keterlibatan orang tua dalam proses belajar anak menjadi pondasi awal untuk memperkuat karakter yang telah dibentuk di lingkungan keluarga. Setelah mendapatkan pendidikan dalam keluarga anak akan siap memperoleh pembelajaran di masyarakat, baik pada jalur pendidikan formal maupun non formal. Namun sering kali masyarakat beranggapan bahwa pendidikan hanya didapatkan di sekolah formal, pada faktanya mereka tidak menyadari bahwa telah melaksanakan pendidikan, baik jalur informal maupun nonformal, seperti belajar bersama ibu, mengikuti pelatihan, les, dan kursus (Indrijati, 2017). Jalur pendidikan di Indonesia telah diatur dalam undang-undang No. 20 Tahun 2003 tentang Sistem Pendidikan Nasional, yaitu terdapat tiga jalur pendidikan, yaitu pendidikan informal, pendidikan formal dan pendidikan nonformal (Sisdiknas, 2003). Peran dari ketiga jalur pendidikan tersebut sebagai penambah, pelengkap dan pengganti (Rohmah, 2014).

Perkembangan anak dapat ditentukan sejauh mana lingkungan mempengaruhinya. Secara teori menurut Bronfenbrenner (M. Racmawati \& A. Kuswanti, 2007) perkembangan anak sangat dipengaruhi oleh sistem lingkungan, yaitu: (1) Mikrosistem, yaitu di mana anak hidup dilingkungan, seperti orang tua, teman sebaya, pendidik dan sekolah, (2) Mesosistem, yaitu hubungan antar mikrosistem, seperti anak dengan orang tua, anak dengan pendidik, orang tua dengan pendidik, keluarga dengan teman sebaya dan lain sebagainya, (3) Ekosistem, yaitu dimana kondisi mempengaruhi perkembangan anak namun tidak terlibat secara langsung, contohnya lingkungan kerja ibu yang dapat mempengaruhi interaksi dengan 
anak (4) Makrosistem, yaitu kondisi anak dipengaruhi oleh budaya dan kebiasaan tempat yang ditinggalinya, (5) Kronosistem, yaitu kondisi dimana berbagai peristiwa yang penting bagi individu maupun sosiokultural. Dari pernyataan di atas bahwa peranan pendidik tidak dapat terlepas dari keterlibatan orang tua dalam pelaksanaan penyelenggaraan pendidikan. Maka diperlukan komunikasi yang sinergi antara pendidik dan orang tua yang menjadi hal penting dalam terlibatnya proses belajar mengajar anak. Komunikasi antar pribadi berarti, komunikasi terjadi saling tatap muka yang memungkinkan setiap orang menangkap reaksi orang lain secara langsung, baik secara verbal atau nonverbal (Mulyana, 2004). Komunikasi orang tua dengan harus tetap dipertahankan selama belajar di rumah berlangsung. Melalui komunikasi orang tua dapat bertanya perihal materi yang akan diajarkan atau hal lainnya yang dianggap sulit dipahami oleh peserta didik. Selain itu pendidik dapat bertanya mengenai hasil perkembangan anak serta memotivasi peserta didik untuk semangat dalam belajar. Namun sering sekali terjadi kesalahpahaman orang tua dengan pendidik karena tidak terjalin komunikasi yang baik. Banyak terjadi kesalahpahaman orang tua dalam pemberian materi yang akan diajarkan kepada anak, sehingga menimbulkan perselisihan orang tua dan anak. Selain itu, sering dijumpai orang tua menganggap bahwa tanggung jawab belajar anak diserahkan kepada sekolah, yang mengakibatkan orang tua tidak mau ikut serta dalam pendampingan belajar anak di rumah. Maka demikian, anak tidak diberikan perhatian khusus dalam pemenuhan fasilitas pembelajaran di rumah. Permasalahan yang sering terjadi selanjutnya, yaitu orang tua menyalahkan pihak sekolah karena anak belajar di rumah dan memaksa untuk dimasukkan walaupun dengan kondisi pandemi saat ini, hal ini disebabkan orang tua mengalami kesulitan dalam membelajarkan anak. Mau tidak mau dalam kondisi ini orang tua menganggap bahwa sekolah hanya memberatkan. Hal ini terjadi karena kurangnya komunikasi antara pendidik dan orang tua dalam terlibatnya proses belajar anak (lestari, 2012).

Kerjasama yang dilakukan oleh orang tua dan pendidik hendaknya dapat terjalin, sebab merekalah menjadi pendorong untuk anak giat belajar. Oleh karena itu, kerjasama antara orang tua dan pendidik dapat menciptakan suasana belajar yang nyaman, aman dan kondusif agar kegiatan belajar bagi anak menyenangkan. Pada hasil penelitian Henderson (Mustofa, 2016), dapat menunjukkan bahwa keterlibatan orang tua terhadap pendidikan anak, yaitu sebagai berikut: 1) Lingkungan keluarga, merupakan lingkungan bagi anak utama dan pertama 2) Keterlibatan orang dalam pendidikan anak dapat meningkatkan prestasi, 3) Keterlibatan orang tua dan sekolah direncanakan terlebih dahulu agar lebih efektif dalam jangka panjang, 4) Keterlibatan orang tua dengan sekolah hendaknya dilakukan sedini mungkin hingga berkelanjutan, 5) Keterlibatan orang tua dan pendidikan anak di rumah dirasa belum cukup, diperlukan keterlibatan orang tua dan sekolah, sehingga peningkatan prestasi anak akan tampak, dan 6) Anak yang memiliki penghasilan orang tua rendah serta minoritas, akan terlihat peningkatan prestasi apabila orang tua terlibat dalam pendidikan anak.

Orang tua dan pendidik menjadi satu kesatuan mendukung belajar anak selama di rumah. Menurut Stephen R. Covey (Yusuf, 2010) peran orang tua sebagai modelling, mentoring, organizing, dan teaching. Kemudian pendidik memiliki peran, yaitu sebagai demonstraktor, motivator, mediator, fasilitator dan evaluator (Cahyani, 2017). Pada masa pandemi Covid-19 bentuk sederhana keterlibatan antara orang tua dan pendidik, yaitu komunikasi. Chattermole \& Robinso (Mustofa, 2016) mengungkapkan pentingnya komunikasi pendidik dan orang tua, yaitu guru mengetahui kebutuhan dan harapan anak, kemudian orang tua mengikuti program yang direncanakan oleh pihak sekolah, orang tua memiliki hak untuk dapat memperoleh informasi, baik program, atau ketentuan yang berlaku demi kelancaran belajar mengajar, komunikasi yang baik membantu kelancaran penyelenggaraan pendidikan. Dengan adanya komunikasi dapat meningkatkan pandangan orang tua dan pendidik mengenai peserta didik dan proses belajar mengajar (Mustofa, 2016). Cara komunikasi yang dilakukan oleh orang tua dan pendidik dapat melalui gadget untuk mempermudah dalam 
mengetahui perkembangan belajar anak selama di rumah. Penggunaan gadget merupakan bentuk nyata dari perkembangan iptek saat ini (Pebriana, 2017). Dengan adanya gadget berbagai fitur aplikasi yang disediakan, baik berupa whatsapp, zoom, google meet, dan lain sebagainya dapat mempermudah interaksi antara pendidik, peserta didik dan orang tua, terutama pada pembelajaran bagi anak usia 3-4 tahun.

Pada anak usia 3-4 tahun, pendidik tidak bisa hanya memberikan berupa penugasan dan materi yang harus dikerjakan dan dikumpulkan, melainkan diperlukan proses belajar yang sesuai dengan perkembangan anak usia dini. Maka bagi anak usia dini diperlukan pendampingan belajar oleh orang tua, sebab mereka belum bisa melaksanakan instruksi yang diberikan oleh pendidik secara mandiri (I. Y. Astuti \& Harun, 2020). Pembelajaran secara daring menjadi pengalaman yang pertama bagi pendidikan anak usia dini khususnya pada anak usia Kelompok Bermain (KB). Tentunya pada anak usia tersebut dalam pembelajaran seperti ini mengalami kesulitan, karena anak usia dini memerlukan suasana belajar di kelas, yaitu berinteraksi dengan pendidik dan teman sebaya. Mereka akan mengalami rasa bosan jika pembelajaran hanya menatap layar. Permasalahan ini menjadi salah satu tugas terbesar bagi pendidik dan orang tua.

Peneliti menemukan fenomena yang menarik di Kelompok Bermain (KB) Kuncup Harapan, yaitu memberikan biaya pendidikan secara gratis bagi peserta didik yang kurang mampu agar tetap terlayani pada pendidikan anak usia dini. Kemudian menggunakan kurikulum 2013 dengan melibatkan orang tua dalam merencanakan dan pelaksanaan pembelajaran menggunakan pendekatan sainstifik metode sentra. Terdapat juga program parenting parents talk yang dilakukan rutin setiap dua minggu sekali melalui komunikasi secara langsung dengan menghadirkan orang tua satu persatu, agar permasalahan atau kesulitan orang tua dalam pola asuh dapat terselesaikan dengan baik dengan menghadirkan ahli psikologi yang berpengalaman pada bidang anak usia dini. Pada masa pandemi program parenting parents talk tetap berjalan, bahkan komunikasi dengan pihak sekolah khususnya pendidik terjalin setiap hari melalui media whatsapp. Selain itu terdapat kegiatan yang telah berjalan selama pandemi Covid-19 pada program parenting, yaitu diadakannya setiap satu bulan sekali pihak sekolah memberikan pembinaan pendampingan belajar pada anak usia dini melalui media google meet, agar orang tua dapat menjadi guru di rumah bagi anak dengan membekali keilmuan dasar pendidikan anak usia dini. Dari kegiatan tersebut terdapat bentuk kegiatan parenting di Kelompok Bermain (KB) Kuncup Harapan, antara lain keterlibatan belajar di rumah, komunikasi, volunteer, dan pengambilan keputusan dalam pendidikan anak. Maka demikian tujuan dari penelitian ini, yaitu mendeskripsikan sinergi orang tua dengan pendidik di Kelompok Bermain (KB) Kuncup Harapan Kota Baru Driyorejo Gresik dalam mendampingi belajar anak pada masa pandemi Covid-19.

\section{METODOLOGI}

Penelitian ini menggunakan pendekatan penelitian kualitatif deskriptif. Penelitian kualitatif deskriptif yaitu mengumpulkan data berdasarkan faktor-faktor yang menjadi pendukung terhadap objek penelitian, kemudian menganalisa faktor-faktor tersebut untuk mencari peranannya (Suharsimi, 2010). Penelitian dilakukan dengan maksud mendeskripsikan keterlibatan pendidik bersinergi dengan orang tua dalam pendampingan belajar anak selama pandemi Covid-19. Lokasi penelitian berada di Kelompok Bermain (KB) Kuncup harapan Kota Baru Driyorejo Gresik, waktu pelaksanaan penelitian selama 6 bulan mulai dari tanggal 13 Juli - 12 Desember 2020. Penelitian ini menggunakan teknik pengambilan sampel dilakukan dengan purposive sampling yaitu menentukan responden berdasarkan kriteria tertentu. Pada penelitian ini bertindak sebagai subjek penelitian, yaitu pendidik dan orang tua dengan kriteria dan jumlah sebagai berikut : pendidik dari KB Kuncup Harapan KBD Gresik sejumlah 3 orang dengan kriteria S1 pendidikan, terlibat pembelajaran daring selama 6 bulan, berpengalaman mengajar lebih dari 5 tahun. Kemudian sampel berikutnya yaitu orang tua KB Kuncup Harapan sejumlah 9 orang dengan kriteria usia 20-35, 
terlibat pendampingan anak belajar daring selama 6 bulan, pendidikan minimal SMA. Teknik pengumpulan data menggunakan data primer dan sekunder. Data primer diperoleh dari hasil wawancara terstruktur dilakukan secara daring menggunakan "Whats App" dan data sekunder berupa dokumen mengenai identitas pendidik, peserta didik, orang tua.

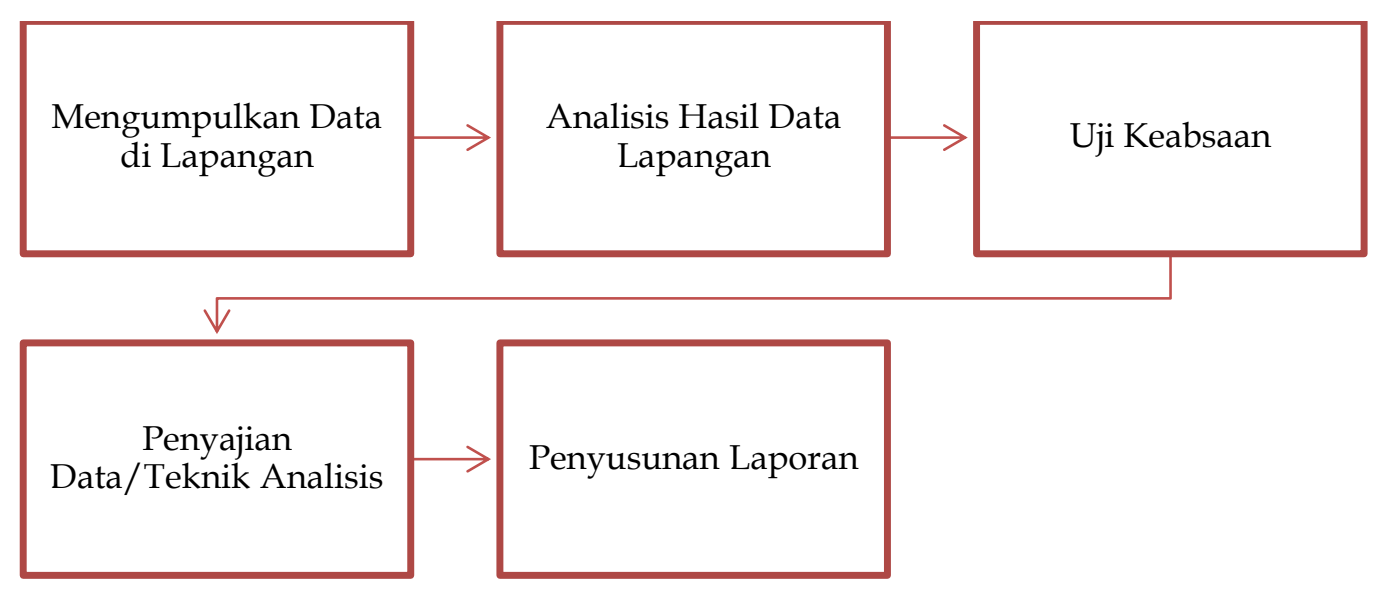

Gambar 1. Alur Penelitian

Teknik keabsahan data yang digunakan penelitian ini, yaitu teknik trigulasi. Teknik trigulasi diartikan sebagai teknik pengumpulan dari sumber data yang telah ada. Selanjutnya teknik analisis data menggunakan analisis Miles dan Hubermen. Miles and Huberman, yaitu analisis data dilakukan secara interaktif dan berlangsung secara terus menerus sampai data sudah jenuh, kemudian dalam aktivitas analisis data, yaitu data reduction, data dispay, dan conclusion.

\section{HASIL DAN PEMBAHASAN}

Pelaksanaan penelitian di Kelompok Bermain (KB) Kuncup Harapan Kota Baru Driyorejo Gresik. Pelaksanaan penelitian selama 6 bulan dimulai tanggal 13 Juli - 12 Desember 2020. Penelitian ini dilakukan untuk mendeskripsikan sinergi orang tua dengan pendidik di Kelompok Bermain (KB) Kuncup Harapan Kota Baru Driyorejo dalam mendampingi belajar anak pada masa pandemi Covid-19. Fokus penelitian antara lain: peran pendidik, peran orang tua dan sinergi orang tua dengan pendidik selama anak belajar dari rumah (BDR).

\section{Peran Pendidik \\ Pendidik Sebagai Demonstraktor}

Pendidik sebagai peran demonstraktor, yaitu memberikan petunjuk kepada peserta didik untuk mudah memahami pesan yang disampaikan. Pendidik tidak hanya menyampaikan pesan melalui lisan, melainkan juga memberikan contoh agar peserta didik lebih mudah dalam memahami materi dari pendidik. Hal ini perlu dilakukan oleh pendidik anak usia dini, sebab anak belum memahami materi yang penyampaiannya secara abstrak. Dibutuhkan contoh dan penjelasan yang kongkrit, baik berupa materi maupun perilaku pendidik terhadap peserta didik. Terdapat dua konteks peran pendidik sebagai demontraktor, yaitu yang pertama dapat menunjukkan sikap yang terpuji dalam aspek kehidupan, sebab pendidik sebagai teladan yang baik untuk peserta didik. Kemudian yang kedua peran pendidik dapat menunjukkan peserta didik untuk dapat mudah dalam memahami mata pelajaran (Septiani, 2019). Hal ini juga dilakukan oleh pendidik Kelompok Bermain (KB) Kuncup Harapan, yaitu memberikan contoh dan penjelasan untuk peserta didik, seperti membuat batik dari tisu, sebelumnya peserta didik memberikan contoh dalam pembuatannya kemudian dijelaskan tahap demi tahap agar anak lebih mudah untuk mengikuti pembuatan 
kreativitas batik dari tisu. Walaupun dalam kondisi belajar di rumah hal ini tetap bisa dilakukan, dengan pendidik membuat tutorial video maupun secara langsung melalui google meet.

Salah satu pendidik mengatakan "Pendidik memiliki tanggung jawab dalam mendampingi setiap sentra. Kelompok Bermain (KB) Kuncup Harapan terdapat lima sentra, yaitu sentra persiapan, sentra agama, sentra seni, sentra bahan alam dan setra balok. Setiap sentra membutuhkan demonstrasi dalam menjelaskan materi khususnya pada sentra seni dan bahan alam. Pada masa pandemi saat ini pendidik lebih menggunakan video dalam mendemonstrasikan materi" (Mujayana, 2020). Penjelasan dari salah satu pendidik di atas, bahwa pembelajaran sentra tetap dilakukan masa pandemi saat ini. Setiap pendidik memiliki tanggung jawab pembelajaran sentra yang dilakukan secara yang dilakukan setiap hari Rabu dan Jumat dengan peserta didik dijadikan satu dalam pembelajarannya sesuai dengan jenis sentra. Pembelajaran sentra ini lebih banyak membutuhkan demonstrasi agar lebih mudah peserta didik dalam memahami.

\section{Pendidik Sebagai Motivator}

Hasil dari wawancara pada penelitian ini bahwa pendidik telah memberikan motivasi diawal dan akhir setiap pembelajaran. Motivasi sangat penting diberikan kepada peserta didik (Emda, 2018). Peserta didik anak usia dini membutuhkan motivasi agar dapat meningkatkan semangat dalam mengikuti pembelajaran, bentuk pemberian motivasi dapat berupa pujian baik melalui verbal maupun nonverbal. Pendidik dibutuhkan keterampilan dalam proses pembelajaran secara daring khususnya pada anak usia dini. Salah satu pendidik mengatakan "Selama pembelajaran di rumah sebagai pendidik harus dapat mengetahui kondisi dan situasi peserta didik apalagi anak usia dini yang susah susah gampang untuk membangun mood dalam belajar" (Endah, 2020)

Pendidik dalam membangun suasana belajar secara daring harus memiliki kreativitas dan inovasi, agar suasana pembelajaran tetap hidup walaupun tidak bersentuhan langsung dengan peserta didik. Salah satu cara yang dilakukan pendidik Kelompok Bermain (KB) Kuncup Harapan agar anak antusias dalam pembelajaran, yaitu dengan memanggil nama peserta didik disetiap pertanyaan atau tugas yang diberikan, sehingga pembelajaran tidak hanya berpusat pada pendidik melainkan berpusat pada peserta didik. Pemanggilan nama bagi anak usia dini merupakan salah satu bentuk motivasi, sehingga mereka merasa bahwa pendidik mengenal dan perhatian dengan anak. Ketika pendidik sudah dapat membangun suasana belajar yang mendukung dengan pemberian motivasi dan perhatian maka peserta didik akan kembali dan terus-menerus untuk ingin selalu belajar. Menurut (Wena, 2010) motivasi belajar merupakan suatu dorongan, baik internal maupun eksternal yang membuat peserta didik semangat, senang belajar dengan serius dan kembali terus menerus selama pelaksanaan pembelajaran.

Motivasi yang diberikan oleh pendidik hendaknya merata dan dilakukan secara rutin. Pemberian motivasi dapat merangsang peserta didik berperan aktif dalam pembelajaran. Hal ini sesuai yang disampaikan oleh (Slameto, 2003) bahwa pendidik harus membangun situasi belajar agar peserta didik dapat berpartisipasi aktif dan dinamis untuk memenuhi kebutuhan belajar serta tercapainya tujuan pembelajaran. Motivasi merupakan hal yang sangat krusial yang harus diperhatikan bagi pendidik. Banyak anak yang tidak berprestasi bukan karena ketidakmampuan mereka dalam memahami materi pembelajaran, melainkan tidak adanya pemberian motivasi yang diberikan oleh pendidik (Moslem et al., 2019). Jatuhnya mental anak biasanya disebabkan oleh perlakukan orang terdekat, salah satunya pendidik. Permasalahan yang sering dijumpai, yaitu memperlakukan peserta didik berdasarkan latar belakang. Hal demikian bukan selayaknya yang dilakukan pendidik. Pendidik sejati mereka yang memahami psikologi anak. Di Kelompok Bermain (KB) Kuncup Harapan latar belakang peserta didik majemuk. Pelayanan yang diberikan oleh pendidik sama, sehingga pendidik tidak hanya menjadi penyampaian materi, melainkan juga pemberian motivasi secara 
psikologi anak. Pendidik Kelompok Bermain (KB) Kuncup Harapan mengatakan bahwa" partisipasi belajar anak selama di rumah sangat antusias dengan selalu tidak pernah absen untuk mengikuti kegiatan pembelajaran secara daring" (Mujayana, 2020). Maka dari itu motivasi dapat membangun persepsi anak untuk selalu belajar apalagi bagi anak usia dini yang dimana harus ditanamkan gemar belajar untuk mempersiapkan jenjang pendidikan selanjutnya.

\section{Pendidik Sebagai Mediator}

Dimasa pandemi saat ini penggunaan media elektronik sangat dibutuh dalam proses belajar mengajar. Penguasaan media menjadi hal yang harus dikuasai oleh pendidik salah satunya dalam penggunaan gadget (Putra, 2017). Beberapa layanan aplikasi pada gadget hendaknya pendidik dapat mengetahui cara menggunakan agar dapat mempermudah proses pembelajaran secara daring, seperti zoom, google meet, whatsapp, ataupun aplikasi belajar yang telah tersedia di playstore atau appstore. Hasil wawancara pada penelitian ini bahwa pendidik pada awalnya merasa kesusahan dan tidak mengerti pengoperasian beberapa aplikasi, seperti zoom dan google meet. Maka diperlukan pelatihan kembali bagi pendidik dengan tetap melaksanakan protokol kesehatan. Kemudian salah satu pendidik mengatakan "Penguasaan media pembelajar sangat penting dikuasai oleh pendidik, salah satunya penggunaan gadget dimasa pandemi saat ini" lanjutnya "secara tidak langsung media komunikasi juga menjadi media pembelajaran yang sangat dibutuhkan" (Endah, 2020).

Pernyataan yang disampaikan oleh salah satu pendidik benar adanya bahwa alat komunikasi gadget merupakan salah satu media pembelajaran di masa pandemi. Maka diberikan penguatan agar pendidik dapat menguasai, serta dapat juga mengajarkan kembali kepada orang tua, sehingga proses belajar mengajar tetap bisa berjalan seperti semula. Pendidik sebagai mediator hendaknya memiliki pemahaman dan penguasaan dalam penggunaan media pembelajaran, karena media pendidikan berfungsi sebagai alat komunikasi untuk mengaktifkan proses belajar mengajar (Maeliah, 2012).

Setelah pendidik Kelompok Bermain (KB) Kuncup Harapan dapat menguasai penggunaan gadget, berupa aplikasi zoom, maka selanjutnya pendidik menyediakan room zoom sebagai penyedia media dalam proses belajar mengajar. Selain penggunaan zoom, pendidik juga menggunakan video untuk dibagikan kepada orang tua agar anak dapat belajar selama di rumah. Beberapa cara yang sudah dilakukan oleh pendidik Kelompok Bermain Kuncup Harapan untuk tetap efektif proses belajar walaupun dengan keterbatasan yang ada. Tidak hanya penggunaan media elektronik yang digunakan, pendidik Kelompok Bermain (KB) Kuncup Harapan masih menggunakan media pembelajaran, seperti media big busy book, boneka tangan, bahan dan alat pembuatan kreasi tangan, dan lain sebagainya. Penggunaan media pembelajaran harus disesuaikan dengan kebutuhan belajar peserta didik dan pendidik harus dapat terampil untuk memilih dan menggunakan media pembelajaran. Maka dari itu, sebaiknya pendidik tidak hanya tahu pengetahuan mengenai media pembelajaran yang digunakan, tetapi juga harus memiliki keterampilan dalam memilih dan menggunakan media tersebut dengan baik (Maeliah, 2012). Sehingga pendidik diharapkan dapat mengikuti perkembangan inovasi pendidikan agar lebih mudah dalam proses belajar mengajar.

\section{Pendidik Sebagai Fasilitator}

Pendidik Kelompok Bermain (KB) Kuncup Harapan telah memberikan beberapa fasilitas untuk memudahkan proses pembelajaran di masa pandemi, antara lain berupa room zoom, bantuan kuota internet, buku tema, bina kreativitas anak, dan lain sebagainya. Peran fasilitator hendaknya dapat memberikan fasilitas untuk memudahkan proses belajar (Maiza \& Nurhafizah, 2019). Salah satu pendidik mengatakan bahwa "Kita sebagai pendidik dan juga fasilitator semaksimal mungkin untuk memberikan fasilitas" (Khotimah, 2020). Pendidik sebagai fasilitator dengan keterbatasan yang ada tetap berusaha semaksimal mungkin 
memberikan kemudahan dalam pelayanan pendidikan. Beberapa kendala yang dialami oleh orang tua merupakan tanggung jawab pendidik untuk mengatasi permasalahan. Jika ada kendala dalam pengoperasian zoom, atau fasilitas lainnya, maka orang tua dapat datang ke sekolah dengan tetap menaati protokol kesehatan. Tugas sebagai pendidik tidak hanya bertanggung jawab untuk menyampaikan materi melainkan fasilitator, yaitu mempermudah peserta didik dalam proses belajar mengajar.

Peran pendidik sebagai fasilitator hendaknya menggunakan fasilitas yang ada untuk menciptakan suasana yang menyenangkan, sehingga anak dapat mengekspor pengetahuan melalui lingkungan belajar yang bersifat fleksibel dengan sumber belajar yang dapat mendorong anak untuk memilih aktivitasnya sendiri. Pada masa pandemi anak diajak membangun suasana belajar yang aktif dengan memanfaatkan benda yang mudah didapatkan oleh anak di sekitarnya, sehingga anak dapat belajar sambil bermain dengan menyenangkan. Menurut Catron dan Allen (Nurani, 2009) mengungkapkan bahwa peran pendidik anak usia dini melebihi fasilitator maupun tutor, dan juga bukan sebagai transfer ilmu, sebab ilmu pengetahuan tidak bisa ditransfer kepada peserta didik, jika tidak ada keaktifan anak di dalamnya. Maka dari itu diperlukan inovasi dan kreativitas bagi pendidik untuk membuat suasana belajar secara daring dapat menyenangkan. Pembelajaran di Kelompok Bermain (KB) Kuncup Harapan dalam mengembangkan pengetahuan dan kreativitas anak memanfaatkan benda sekitar, contoh membuat batik dari tisu. Pendidik terlebih dahulu mencontohkan pembuatan batik dari tisu, kemudian diikuti peserta didik dengan menggunakan tisu, pewarna makanan, dan karet. Maka secara aktif anak mengikuti pembelajaran selama di rumah. Pendidik sebagai fasilitator bukan hanya sebagai transfer ilmu melainkan juga sebagai pendamping pendidikan bagi anak. Arti pendamping disini bukan pendidik sebagai pemberi ilmu utama, melainkan anak dapat mengekspor pengetahuan dengan caranya sendiri.

\section{Pendidik Sebagai Evaluator}

Pendidik sebagai evaluator, yaitu pendidik bertugas sebagai memberikan nilai perkembangan peserta didik selama belajar dengan memperhatikan prosedur dan metode yang telah ditetapkan (Sundari, 2017). Pendidik di Kelompok Bermain (KB) Kuncup Harapan telah memberikan penilaian belajar anak selama pandemi. Penggunaan teknik penilai tetap sama menggunakan catatan hasil karya, anekdot, dan skala pencapaian perkembangan anak usia dini. Penilaian dilakukan setiap hari di akhir pembelajaran. Salah satu pendidik mengatakan“Penilaian dilakukan setiap hari dengan menggunakan ketiga teknik, yaitu catatan hasil karya, anekdot dan skala pencapaian perkembangan anak usia dini, penilaian ini bertujuan agar dapat melihat perkembangan anak, sehingga pendidik lebih mudah untuk memberikan treatment kebutuhan belajar kepada anak" (Endah, 2020)

Pemberian treatment akan kebutuhan belajar disesuaikan dengan kemampuan anak. Pendidik yang profesional tidak hanya menyampaikan materi melainkan juga dapat mengevaluasi jalannya pembelajaran. Evaluasi harus dilakukan baik kepada peserta didik maupun pendidik agar diharapkan proses belajar mengajar dapat berjalan seefektif mungkin walaupun dalam masa pandemi saat ini. Dengan keterbatasan interaksi anak dan pendidik, semaksimal mungkin pendidik dapat menilai perkembangan anak. Perkembangan prestasi anak juga merupakan tanggung jawab pendidik. Maka dari itu pendidik Kelompok Bermain (KB) Kuncup Harapan tidak hanya memberikan penilaian secara produk melainkan juga proses jalannya anak selama belajar.

Hasil evaluasi belajar anak di Kelompok Bermain (KB) Kuncup Harapan berupa rapor yang dibagikan di akhir semester. Tujuan pemberian rapor agar orang tua dapat melihat perkembangan anak selama satu semester. Melalui pemberian evaluasi, orang tua dapat mudah mengetahui potensi, bakat, minat dan kelemahan anak pada bidang tertentu. Selain itu juga sebagai bahan evaluasi pendidik selama mengajar. Sebab fungsi dari evaluasi, yaitu untuk menentukan pencapaian belajar anak sesuai dengan tujuan, dan menentukan 
keberhasilan pendidik dalam melaksanakan program (Sundari, 2017). Pendidik dalam pemberian penilaian harus objektif mungkin yang harus sesuai dengan perkembangan anak. Hendaknya pendidik harus memahami teori perkembangan anak, agar pendidik tidak menganggap anak pintar berdasarkan kemampuan matematika dan sains, melainkan juga terdapat kecerdasan majemuk yang berbeda dimiliki setiap anak. Sebab anak bersifat unik, yaitu memiliki potensi, bakat dan minat yang berbeda-beda. Melalui evaluasi, pendidik dengan mudah untuk mengembangkan konsep pembelajaran yang sesuai dengan kebutuhan belajar peserta didik.

\section{Peran Orang Tua \\ Orang Tua Sebagai Modelling}

Hasil dari wawancara dengan orang tua pada penelitian ini, bahwa peran orang tua sebagai modelling bisa dilihat dari aktivitas bersama dengan anak di rumah. Beberapa orang tua di Kelompok Bermain (KB) Kuncup Harapan untuk mengisi waktu senggang bersama anak selama di rumah dengan melakukan kegiatan, seperti bersih-bersih, bermain bersama, belajar, mengaji, mengajak anak memasak dan lain sebagainya. Salah satu orang tua mengatakan "Kegiatan bersama anak di rumah, antara lain mengajak memasak bersama, bersih-bersih rumah, mengaji, bermain dan beribadah" (Utami, 2020). Dengan melalui kegiatan positif selama di rumah, maka secara langsung anak akan meniru apa yang dilakukan oleh orang tua. Anak akan meniru orang tua, terhadap apa yang dilihat baik perilaku positif maupun negatif dari kebiasaan, pergaulan, perilaku atau aktivitas yang dilakukan orang tua (Rakhmawati, 2015). Sebab menurut teori belajar sosial, bahwa orang tua sebagai modelling, yaitu anak melakukan kegiatan belajar dengan cara meniru perilaku orang, terutama orang tua selama berada di rumah (Yanto \& Syaripah, 2017). Maka dari itu orang tua harus memberikan contoh sikap yang baik kepada anak, karena keluarga merupakan salah satu pusat pendidikan anak (Alfiana, 2013). Untuk menumbuhkan sikap yang baik dapat dilakukan orang tua sepanjang waktu, baik dalam bermain dan belajar bersama anak. Orang tua sebaiknya memiliki keinginan kuat mengembangkan diri agar dapat mendidik anak selama di rumah. Dengan demikian pembelajaran selama pandemi yang dilaksanakan di rumah dapat berlangsung secara efektif (Fauziddin et al., 2021).

Penanaman budi pekerti pada anak dapat dilakukan orang tua dalam kehidupan sehari-hari sebagai contoh, dengan belajar di alam terbuka. Dalam menanamkan kepedulian anak terhadap alam, maka orang tua memberikan contoh perilaku merawat tanaman dan juga memberikan penjelasan bahwa tanaman merupakan makhluk hidup seperti kita, yang perlu dirawat dengan baik dengan cara menyiram, memberi pupuk dan tidak boleh merusaknya. Melalui kegiatan berkebun, anak secara langsung akan menirukan sikap yang dicontohkan oleh orang tua untuk tetap menjaga kelestarian alam. Sebagai contoh lain di masa pandemi ini orang tua dapat menumbuhkan rasa cinta kepada Tuhan melalui ibadah bersama, seperti shalat bagi orang muslim. Pemberian contoh perilaku yang berkarakter sangat diperlukan bagi anak, sebab pendidikan utama dan pertama didapatkan melalui keluarga. Maka dari itu pendidikan keluarga harus kuat ditanamkan anak sebelum mereka mendapatkan pendidikan di masyarakat. Dengan ini anak memiliki karakter diri yang kuat dalam menghadapi persoalan di masa depannya.

Selama belajar di orang tua juga bertindak sebagai modelling harus selalu dapat memberikan motivasi pada anak. Anak pada dasarnya memiliki motivasi, motivasi tersebut didapatkan dari dorongan orang terdekat seperti orang tua (Lilawati, 2020). Setiap apa yang dikatakan dan dilakukan oleh orang tua dianggap anak sebagai hal baik, maka dari itu hendaknya orang tua berhati-hati berperilaku dan berkata di hadapan anak. Dengan memberikan motivasi dengan kata-kata dapat menumbuhkan semangat anak dalam proses belajarnya, sebagai contoh pemberian motivasi kepada anak di Kelompok Bermain (KB) Kuncup Harapan, "Damay pintar dan hebat, bisa membuang sampah sendiri di tempat sampah" (Natalia, 2020) 
Motivasi yang diberikan membuat anak akan melakukan kegiatan itu lagi dan lagi. Pemberian pujian dapat menumbuhkan semangat untuk terus melakukan hal yang dianggap anak selalu mendapatkan reward. Maka dari itu menumbuhkan moral dan akhlak anak berasal dari proses peniruan dari orang tua maupun pendidik. Sebab pengasuhan dapat mempengaruhi pembentukan perilaku moral anak (Jannah, 2012). Pada masa pandemi saat ini, orang tua berperan penting dalam membelajarkan anak dengan baik. Lingkungan keluarga dapat mencerminkan perilaku anak, jika anak dalam bersosial baik maka otomatis perilaku dalam keluarga baik pula. Perlu diingat bagi orang tua bahwa anak usia dini merupakan peniru ulung yang dimana belum bisa dipertimbangkan dengan baik perilaku yang dicontohnya, oleh karena itu orang tua harus dapat mengembangkan perilaku anak sesuai dengan norma budaya di masyarakat dan tata nilai secara umum (Puspita, 2010).

\section{Orang tua Sebagai Mentoring}

Dari hasil wawancara dengan orang tua Kelompok Bermain (KB) Kuncup Harapan, bahwa intensitas pertemuan orang tua dengan anak sering dan kualitas dalam mendampingi anak belajar di masa pandemi sangat baik. Salah satu orang tua mengatakan "Kualitas dalam intensitas pertemuan dengan anak sangat baik, ditambah saat pandemi semua aktivitas di rumah" (S. L. Astuti, 2020). Kualitas waktu antara anak dan orang tua dapat membangun kebersamaan antar anggota keluarga (Kurniati et al., 2020). Semakin intens pendampingan anak belajar, maka hasil belajar anak semakin baik dan sebaliknya semakin jarang orang tua mendampingi anak, maka hasil belajar anak tidak maksimal (Retno, 2013). Kemudian yang dirasakan oleh orang tua dalam mendampingi anak belajar selama pandemi Covid-19 mengatakan bahwa "Lumayan kuwalahan, karena harus membagi tugas antara jadi ibu, jadi guru daring kemudian banyak bersabar karena kadang-kadang anak tidak menurut" (Karmilawati, 2020). Pendampingan belajar anak selama pandemi merupakan tugas tambahan orang tua menjadi pendidik di rumah. Dalam kehidupan normal yang biasa orang tua hanya mendampingi anak belajar dalam mengerjakan tugas, saat ini orang tua sebagai pengganti pendidik di sekolah, yaitu mengajar dan mendidik (Lilawati, 2020). Maksud dari pernyataan tersebut, yaitu orang tua mengajar ilmu pengetahuan dan juga mendidik untuk membentuk karakter anak. Maka dari itu orang tua di masa pandemi juga bertindak sebagai mentoring belajar bagi anak.

Mentoring, dapat diartikan suatu kemampuan dalam membangun dan memberikan perhatian, dan perlindungan kepada seseorang secara mendalam dengan jujur dan tanpa syarat (Susilowati, 2019). Dari penjelasan tersebut arti dari makna mentoring sangat pas dengan keterikatan antara orang tua dan anak. Orang tua sejatinya akan memberikan kasih sayang dan dukungan bagi anak. Oleh karena itu, orang tua tidak mau jika anaknya tidak mendapatkan pengetahuan selama pandemi ini. Dengan meluangkan waktu untuk mendampingi belajar, maka anak tidak akan tertinggal dengan teman-teman yang lainnya. Orang tua sebagai mentor berperan dalam mengembangkan potensi, minat dan bakat yang dimiliki anak. Dilihat dari hasil penelitian dokumentasi anak selama belajar di rumah, orang tua selalu mendampingi dan membantu anak untuk menyelesaikan tugas, selain itu juga memberikan penjelasan lebih mendalam mengenai materi. Dalam mendampingi anak selama di rumah, orang tua harus belajar kembali agar apa yang disampaikan pendidik dapat dimengerti anak melalui penjelasan orang tua. Orang tua sangat dibutuhkan anak dimasa pandemi sebagai pendamping belajar. Maka dari itu, hendaknya orang tua meluangkan waktu untuk belajar bersama dimasa pandemi khususnya pada anak usia dini yang membutuhkan kasih sayang dan perlindungan orang tua.

\section{Orang Tua Sebagai Organizing}

Orang tua juga bertindak sebagai organizing selama anak belajar di rumah. Bagi orang tua kebutuhan belajar anak tidak hanya menyediakan fasilitas yang diperlukan, melainkan 
juga mengorganisir dalam membantu tugas sekolah anak, seperti yang dikatakan oleh salah satu orang tua, yaitu

"Selain mengorganisasi fasilitas anak selama belajar dari rumah, orang tua juga mengkoordinasi tugas sekolah serta mengarahkan dan mengembangkan potensi melalui kegiatan bersama" (Sari, 2020). Maka dari itu agar proses belajar mengajar anak berjalan secara efektif, hendaknya orang tua, 1) Menyediakan fasilitas belajar, baik berupa gadget, buku, alat tulis dan media pengembangan lainnya. Diperlukan juga organisir dalam mempersiapkan bahan dan alat belajar secara daring. Bagi anak usia dini di Kelompok Bermain (KB) Kuncup Harapan, orang tua sudah secara aktif untuk mengorganisasi kebutuhan belajar, seperti pada pembelajaran melipat bunga tulip.

Orang tua sudah menyediakan perlengkapan yang dibutuhkan untuk anak dalam mengikuti pembelajaran melipat bunga tulip. Dengan kesediaan orang tua dalam mengorganisir kebutuhan belajar anak, maka proses pembelajaran dapat berlangsung secara efektif. 2) Orang tua mengorganisir tugas pembelajaran anak di sekolah. Orang tua harus selalu memantau bagaimana anak menyelesaikan tugas. Apabila anak merasa kesulitan dalam menyelesaikan tugas, maka peran orang tua membantu dan membimbing anak, bukan berarti orang tua yang mengerjakan tugas sekolah tersebut. Peran orang tua di Kelompok Bermain (KB) Kuncup Harapan membimbing anak dalam menyelesaikan tugas, hal yang dirasa sulit bagi anak usia dini, 3) Orang tua mengembangkan potensi yang dimiliki anak dengan diasah melalui kegiatan bersama dengan orang tua, seperti melukis, menari, olahraga, bermusik dan lain sebagainya. Pengembangan bakat dan minat bagi peserta didik Kelompok Bermain (KB) Kuncup Harapan dilakukan orang tua di rumah secara mandiri dengan melibatkan anak pada kegiatan orang tua, sehingga anak tidak merasa bosan berada di rumah selama ada pandemi Covid-19. Maka dari penjelasan tersebut, arti dari organizing menurut Stephen R. Covey (Yusuf, 2014) yaitu keluarga dianalogikan sebagai perusahaan kecil yang saling bekerjasama, menyelesaikan tugas dan masalah, serta memenuhi kebutuhan keluarga. Oleh karena itu, dimasa pandemi saat ini dukungan keluarga sangat berarti khususnya pada anak yang belajar di rumah secara daring sangat memerlukan kerjasama orang tua demi keberhasilan proses belajar mengajar.

\section{Orang Tua Sebagai Teaching}

Orang tua sebagai guru pertama yang dikenal anak dalam lingkungan belajar. Orang tua tidak hanya merawat secara fisik anak, melainkan juga bertanggung jawab dalam mendidik. Kepribadian seseorang dapat dilihat bagaimana pendidikan di rumah berlangsung. Lingkungan keluarga mengajarkan hukum-hukum dasar kehidupan, yaitu anak dapat mengetahui apa yang dikerjakan dan memahami alasan kenapa hal tersebut dikerjakan. Hasil wawancara pada penelitian ini orang tua mengatakan "Anak usia dini lebih aktif dalam bertanya, kita orang tua sebagai madrasah pertama, maka pertanyaan tersebut harus terjawab, walaupun kadang-kadang pertanyaan yang diajukan tidak penting bagi kita" (Christina, 2020). Orang tua sebagai guru sejatinya dapat mengetahui kebutuhan belajar anak, apalagi di masa pandemi saat ini. Ketika anak bertanya mengenai hal yang tidak diketahui, sebaiknya orang tua membantu dalam menjawab dengan penjelasan yang disesuaikan dengan usia. Menurut Bjorkland (Mustofa, 2016) Orang tua hendaknya menjadi guru yang baik bagi anak, yaitu harus berperan sebagai pengamat, melakukan elaborasi, sebagai model, melakukan evaluasi dan melakukan perencanaan. Orang tua sebagai guru, yaitu memiliki tanggung jawab dalam mendidik dan mengajar bagi anak (Lilawati, 2020).

Orang tua dalam mendidik dan mengajar harus dapat mengerti cara menghadapi anak selama pandemi saat ini. Terdapat tiga peran orang tua untuk meningkatkan dalam mendidik anak yaitu; 1) mengatur jadwal kegiatan bermain dan belajar anak selama di rumah, hendaknya orang tua selalu memantau jadwal kegiatan selama di rumah, jangan sampai anak selama di rumah kegiatannya hanya bermain dan meninggalkan kewajiban dalam belajar, 2) memantau perkembangan anak dalam kemampuan akademik yang menjadi tanggung jawab orang tua. Pendidik hanya memberikan materi, selanjutnya orang tualah yang menjadi 
perpanjangan tangan pendidik dalam menyampaikan pengetahuan, 3) memantau kepribadian anak, sebab keluargalah pembentuk karakter pertama dan utama bagi anak (Siregar, 2013). Maka dari itu, pentingnya peran keluarga untuk menanamkan kebiasaan dan tingkah laku dalam menanamkan sikap moral dan agama sesuai dengan usia dan kultur (Zahrok \& Suarmini, 2018).

\section{Sinergi Orang Tua dan Pendidik Selama Anak Belajar di Rumah}

Pentingnya sinergi antara orang tua dan pendidik untuk bekerjasama dalam membantu anak belajar (Yanti \& Rivaie, 2013). Terdapat hubungan erat antara guru selaku pendidik formal dan orang tua sebagai pendidik nonformal (Yanti \& Rivaie, 2013). Tidak dapat terpisahkan peran pendidikan formal dan pendidikan non formal, karena kedua jalur pendidikan tersebut bersifat pelengkap, penambah dan pengganti (Rohmah, 2014). Guna mendapatkan hasil belajar anak yang terbaik, maka diperlukan tenaga pendidik yang profesional yang bertindak sebagai lembaga formal yang mengelola jalannya pendidikan dan orang tua sebagai pembimbing nonformal yang bertindak sebagai fasilitator, yaitu menyediakan fasilitas dalam menunjang anak belajar, seperti sarana prasarana, buku, alat tulis, transportasi dan lain sebagainya. Sinergi orang tua dengan pendidik sangat dibutuhkan untuk perkembangan peserta didik. Perhatian yang diberikan orang terdekat membuat anak menumbuhkan rasa kepercayaan diri. Maka dari itu orang tua dan pendidik memiliki tanggung jawab atas perkembangan anak khususnya pada anak usia dini. Tanggung jawab orang tua sebagai pendidik di rumah, yaitu mengasuh dan mendidik anak hingga dewasa dengan berperilaku baik, memahami aturan dan norma budaya maupun masyarakat. Tanggung jawab sebagai pendidik melindungi, membimbing, serta memberikan pengajaran dan pendidikan sesuai dengan standart kurikulum.

Peran orang tua dengan pendidik tidak dapat terlepaskan bagi tumbuh kembang anak, sebab kedua peran tersebut merupakan orang terdekat bagi anak, sehingga pendidik dan orang tua menjadi model dan teladan bagi anak. Menjadi teladan merupakan sosok perilaku seseorang yang dapat ditiru, sebagai panutan (Damsy \& Rivaei, n.d.). Jika anak tidak menjadi teladan yang baik bagi dirinya, hal ini disebabkan karena faktor lingkungan sekitar tidak menjadi panutan yang baik bagi anak. Tugas tersebut menjadi tanggung jawab orang tua dan pendidik, untuk mencegah anak salah memilih lingkungan. Agar anak tidak masuk pada lingkungan yang salah, orang tua dan pendidik hendaknya memberikan perhatian berupa motivasi, menjadi pelindung bagi anak, mengarahkan terhadap hal-hal yang positif, diberikan pengertian dan juga sebagai sahabat bagi anak. Hal demikian dilakukan demi masa depan anak yang berguna bagi masyarakat luas. Nilai-nilai yang telah ditanamkan anak, baik oleh pendidik maupun orang tua menjadikan acuan dan pedoman dalam menghadapi konflik di masyarakat.

Hubungan antara orang tua dan pendidik, merupakan hubungan timbal balik kerjasama dalam mendampingi anak. Burton (Nasution, 2010) mengatakan bahwa kerjasama, yaitu rangkaian kegiatan yang dilakukan oleh beberapa orang secara bersama yang menimbulkan hasil yang tidak akan timbul jika hanya dilakukan satu orang. Hasil penelitian Henderson (Mustofa, 2016) menunjukkan peningkatan prestasi anak apabila orang tua mendukung dan peduli pada mereka. Dalam mendampingi belajar anak selama di masa pandemi ini memerlukan dukungan dari orang tua dan pendidik agar tujuan dari proses belajar anak tercapai (Yanti \& Rivaie, 2013). Namun pada faktanya selama mendampingi belajar di rumah, pendidik dan orang tua hanya berfokus pada perkembangan kognitif, yaitu hanya diberikan tugas-tugas pengetahuan, sehingga tujuan pembentukan karakter tenggelam atas banyaknya tugas bersifat kognitif. Maka dari itu menurut (Mattewakkang, 2020) pendampingan belajar pada anak selama di rumah diharapkan orang tua dan pendidik tidak terfokus pada perkembangan anak secara kognitif, melainkan juga pada pembelajaran yang bermakna. Selama belajar di rumah beban tugas yang diberikan oleh pendidik kepada peserta didik dikatakan sangat berat, sehingga membuat orang tua merasa terbebani untuk 
mendampingi belajar anak. Oleh karena itu, hendaknya kegiatan atau tugas yang diberikan harus disesuaikan dengan tingkat perkembangan anak, dengan mengolaborasikan pendidik yang berperan aktif memberikan kegiatan pembelajaran dan orang tua sebagai bertindak pelaksanaan (Lilawati, 2020).

Sinergi antara orang tua dan pendidik untuk mendampingi anak belajar di rumah selama pandemi dapat dilakukan melalui komunikasi. Saat ini kerjasama antara orang tua dan pendidik tidak bisa saling bertatapan langsung di sekolah. Dipelukannya komunikasi yang aktif secara daring untuk tetap saling terhubung. Dengan adanya gadget, hal-hal yang bersangkutan mengenai tujuan belajar anak yang diberikan oleh pendidik dapat tersampaikan. Perkembangan anak belajar selama di rumah dipantau pendidik melalui orang tua dengan secara daring. Orang tua bertugas memberikan laporan hasil perkembangan anak melalui hasil tugas yang telah diberikan oleh pendidik. Selain itu juga orang tua memberi tahu hambatan anak selama belajar di rumah kepada pendidik. Menurut hasil wawancara dengan orang tua Kelompok Bermain (KB) Kuncup Harapan mengatakan bahwa “Telah melakukan komunikasi dengan pendidik secara intens, pendidik memberikan informasi melalui whatsapp grup, sehingga informasi mengenai waktu pembelajaran dengan zoom maupun pemberian tugas tersampaikan dengan baik kepada orang tua, lanjutnya jika terdapat kendala saat pembelajaran daring, maka pendidik langsung merespon dengan baik" (Winarsih, 2020). Dengan tetap menjaga komunikasi yang baik antara orang tua dan pendidik dalam proses belajar mengajar dapat berjalan dengan lancar. Kerjasama yang dilakukan oleh pendidik dan orang tua dapat menjadi pendorong anak giat belajar. Dengan demikian hendaknya orang tua dan pendidik menciptakan suasana belajar yang nyaman, aman dan kondusif agar belajar bagi anak menyenangkan.

Maka dari itu bentuk kerjasama orang tua dan pendidik Kelompok Bermain (KB) Kuncup Harapan pada pandemi saat ini dengan melalui program parenting antara lain, 1) Keterlibatan belajar di rumah, pada masa pandemi saat ini KB (Kelompok Bermain) Kuncup Harapan mengajak orang tua untuk terlibat belajar di rumah bersama anak. Orang tua disini bertindak sebagai pengganti guru di sekolah dengan mendampingi belajar secara daring melalui google meet, hal ini diperlukan karena anak belum bisa mengoperasikan gadget. Selain itu orang tua mendampingi dalam menyelesai tugas sekolah anak yang tentunya bukan orang tua yang mengerjakan melainkan anak secara mandiri. Orang tua hanya bertindak sebagai fasilitator dalam memenuhi kebutuhan belajar anak. Selain itu terdapat kegiatan yang mengasah bakat dan minat, Kelompok Bermain (KB) Kuncup Harapan mengusahakan secara optimal dalam mengembangkan potensi anak dengan bantuan orang tua untuk tetap melakukan kegiatan ekstrakurikuler berupa seni tari, bernyanyi, TIK, dan melukis yang tentunya mendapatkan pengarahan dari pendidik bersangkutan. 2) Komunikasi, pada masa pandemi terdapat keterbatasan manusia untuk saling bertemu agar terhindar dari penyebaran Covid-19.

Dengan adanya keterbatasan ini tidak menjadi penghalang orang tua untuk berkomunikasi oleh pendidik Kelompok Bermain Kuncup Harapan. Bentuk komunikasi orang tua dan pendidik dengan pendekatan interpersonal dan kelompok melalui media sosial whatsapp maupun google meet. Komunikasi interpersonal dilakukan setiap hari orang tua kepada pendidik dalam memberikan informasi kegiatan pembelajaran. Selain itu setiap dua minggu sekali orang tua melakukan komunikasi secara interpersonal kepada ahli psikologi anak usia dini untuk membahas hambatan pola asuh anak selama anak belajar di rumah. Kemudian terdapat komunikasi kelompok yang dilakukan oleh pihak Kelompok Bermain (KB) melalui kegiatan yang diadakan setiap satu bulan sekali, yaitu pembinaan pendampingan belajar selama belajar di rumah yang dihadiri oleh ahli dalam bidang pendidikan anak usia dini, melalui kegiatan diskusi kelompok ini orang tua dapat memahami bagaimana pola asuh, mendampingi anak belajar dan menjadi guru pribadi anak selama di rumah. 
Komunikasi yang intens membuat orang tua merasa diperhatikan oleh pihak sekolah, sehingga hal ini juga menjadi strategi untuk memikat minat orang tua untuk menyekolahkan di Kelompok Bermain (KB) Kuncup Harapan, sebab pemberian pelayanan yang terbaik akan membentuk kepercayaan orang tua. 3) Volunteer, pada masa pandemi orang tua Kelompok Bermain (KB) diajak serta dalam kegiatan sosial untuk saling berbagi melalui kegiatan amal kasih bagi yang terdampak pandemi Covid-19. Melalui kegiatan ini orang tua, pendidik dan anak diajak dalam bekerjasama saling membantu orang lain yang membutuhkan dengan diawali dari pihak terdekat warga sekolah. Selain itu kegiatan tersebut, orang tua Kelompok Bermain (KB) Kuncup harapan diajak serta bersedia mendampingi anak belajar di rumah dan berperan aktif dalam kegiatan di sekolah secara daring dan 4) Pengambilan keputusan dalam pendidikan anak, orang tua diajak terlibat langsung dalam perencanaan dan pelaksanaan pembelajaran anak. Disini pendidik tidak bertindak sebagai dominan dalam penguasaan pembelajaran. Orang tua diajak untuk mengambil keputusan yang tentunya dapat ditentukan sesuai dengan kebutuhan belajar anak apalagi pada masa pandemi. Sebagai contoh program tahunan pembelajaran, orang tua diajak serta dalam rapat kepada kepala sekolah untuk mengetahui kesanggupan orang tua terhadap kegiatan satu tahun ke depan dengan keterbatasan yang ada. Pengambilan keputusan ini dilakukan agar proses belajar mengajar dapat berjalan lancar, karena tanpa persetujuan orang tua program kegiatan bagus sekalipun tidak dapat berjalan sesuai dengan harapan. Oleh karena itu, diharapkan kerjasama antara orang tua dan pendidik dapat berjalan dengan baik dalam mendampingi belajar anak di rumah agar dapat menghantarkan tujuan pendidikan bagi anak usia dini, yaitu mempersiapkan jenjang pendidikan selanjutnya dan mencerdaskan anak bangsa.

\section{SIMPULAN}

Sinergi antara pendidik dan orang tua sangat penting di masa pandemi saat ini, apalagi bagi anak usia dini. Peran pendidik dan orang tua memiliki tanggung jawab masing-masing dalam mendampingi anak belajar. Pendidik dan orang tua sebagai orang terdekat bagi anak menjadi pelindung di masa pandemi. Maka dari itu terdapat bentuk kegiatan parenting Kelompok Bermain Kuncup Harapan selama pandemi Covid-19, yaitu keterlibatan belajar di rumah, komunikasi, volunteer, dan pengambilan keputusan dalam pendidikan anak. Keterlibatan diperlukan bagi anak selama belajar di rumah agar tujuan dari proses pendidikan dapat tercapai, serta mempersiapkan anak ke jenjang pendidikan selanjutnya.

\section{UCAPAN TERIMA KASIH}

Ucapan terima kasih kepada kaprodi Pendidikan Luar Sekolah Pascasarjana Universitas Negeri Surabaya memberikan kesempatan untuk penelitian ini dan Kelompok Bermain (KB) Kuncup Harapan telah membantu dan menyukseskan pelaksanaan penelitian belajar dari rumah selama pandemi Covid-19.

\section{DAFTAR PUSTAKA}

Alfiana, E. N. (2013). Pola Asuh Orang Tua terhadap Anak dalam Keluarga Pada Bidang Pendidikan di Dusun Pandaan Desa Pandanan Kecamatan Wonosari Klaten. Universitas Negeri Yogyakarta.

Astuti, I. Y., \& Harun, H. (2020). Tantangan Guru dan Orang Tua dalam Kegiatan Belajar Dari Rumah Anak Usia Dini pada Masa Pandemi Covid-19. Jurnal Obsesi: Jurnal Pendidikan Anak Usia Dini, 5(2), 1454-1463. https://doi.org/10.31004/obsesi.v5i2.808

Astuti, S. L. (2020). Orang Tua Sebagai Mentoring. Hasil Wawancara Pribadi.

Christina, E. A. (2020). Orang Tua Sebagai Teaching. Hasil Wawancara Pribadi.

Damsy, Y. J., \& Rivaei, W. (n.d.). Peran Orang Tua dan Guru dalam Mengatasi Sikap dan Perilaku Menyimpang Anak. Jurnal Pendidikan Dan Pembelajaran Khatulistiwa, 3(2). 
Emda, A. (2018). Kedudukan motivasi belajar siswa dalam pembelajaran. Lantanida Journal, 5(2), 172. https:// doi.org/10.22373/lj.v5i2.2838

Endah, C. (2020a). Pendidik Sebagai Evaluator. Hasil Wawancara Pribadi.

Endah, C. (2020b). Pendidik Sebagai Mediator. Hasil Wawancara Pribadi.

Endah, C. (2020c). Pendidik Sebagai Motivator. Hasil Wawancara Pribadi.

Fauziddin, M., Mayasari, D., \& Rizki, L. M. (2021). Effective Learning for Early Childhood during Global Pandemic. Al-Ishlah: Jurnal Pendidikan, 13(1). https://doi.org/10.35445/alishlah.v13i1.458

Indrijati, H. (2017). Psikologi Perkembangan \& Pendidikan Anak Usia Dini. KENCANA.

Jannah, H. (2012). Bentuk pola asuh orang tua dalam menanamkan perilaku moral pada anak usia di kecamatan ampek angkek. Jurnal Ilmiah Pesona PAUD, 1(2).

Karmilawati. (2020). Orang Tua Sebagai Mentoring. Hasil Wawancara Pribadi.

Khotimah, K. (2020). Pendidik Sebagai Fasilitator. Hasil Wawancara Pribadi.

Kurniati, E., Nur Alfaeni, D. K., \& Andriani, F. (2020). Analisis Peran Orang Tua dalam Mendampingi Anak di Masa Pandemi Covid-19. Jurnal Obsesi : Jurnal Pendidikan Anak Usia Dini, 5(1), 241. https:// doi.org/10.31004/obsesi.v5i1.541

Lai, C.-C. C., Shih, T.-P. P., Ko, W.-C. C., Tang, H.-J. J., \& Hsueh, P.-R. R. (2020). Severe acute respiratory syndrome coronavirus 2 (SARS-CoV-2) and coronavirus disease-2019 (COVID-19): The epidemic and the challenges. International Journal of Antimicrobial Agents, 55(3), 105924. https:// doi.org/10.1016/j.ijantimicag.2020.105924

lestari, S. (2012). Psikologi Keluarga: Penanaman Nilai dan Penanganan Konflik dalam Keluarga,. Jakarta:Prenada Media Group, 50.

Lilawati, A. (2020). Peran Orang Tua dalam Mendukung Kegiatan Pembelajaran di Rumah pada Masa Pandemi. Jurnal Obsesi: Jurnal Pendidikan Anak Usia Dini, 5(1), 549. https:// doi.org/10.31004/obsesi.v5i1.630

Maeliah, M. (2012). Peran Guru dalam Menyiapkan Kompetensi Kerja Siswa Sesuai Tuntutan Dunia Kerja di Industri Busana. Prosiding APTEKINDO, 6(1).

Maiza, Z., \& Nurhafizah, N. (2019). Pengembangan Keprofesian Berkelanjutan dalam Meningkatkan Profesionalisme Guru Pendidikan Anak Usia Dini. Jurnal Obsesi: Jurnal Pendidikan Anak Usia Dini, 3(2), 356. https:// doi.org/10.31004/obsesi.v3i2.196

Mattewakkang, A. J. (2020). Arah Pendidikan Di Masa Pandemi Covid-19 (Refleksi Hari Pendidikan Nasional). Takalarterkini.Com.

Moslem, M. C., Komaro, M., \& Yayat, Y. (2019). Faktor-Faktor yang Menyebabkan Rendahnya Motivasi Belajar Siswa dalam Mata Pelajaran Aircraft Drawing di SMK. Journal of Mechanical Engineering Education, 6(2), 258-265.

Mujayana, I. (2020a). Antusias Anak Dalam Belajar. Hasil Wawancara Pribadi.

Mujayana, I. (2020b). Pendidik Sebagai Demonstraktor. Hasil Wawancara Pribadi.

Mulyana, D. (2004). Komunikasi efektif: suatu pendekatan lintasbudaya. Remaja Rosdakarya. Mustofa, B. (2016). Dasar-Dasar Pendidikan Anak Pra Sekolah. Parama Ilmu.

Muttakhidah, R. R. I. (2016). Pergeseran Perspektif "Human Mind" John Locke Dalam Paradigma Pendidikan Matematika. AdMathEdu: Jurnal Ilmiah Pendidikan Matematika, Ilmu Matematika Dan Matematika Terapan, 6(1). https:// doi.org/10.12928/admathedu.v6i1.4761

Nasution. (2010). Didaktik Asas-Asas Mengajar. Bumi Aksara.

Natalia. (2020). Pemberian Motivasi. Hasil Wawancara Pribadi.

Nurani, Y. S. (2009). Konsep Dasar PAUD. Indeks.

Pebriana, P. H. (2017). Analisis Penggunaan Gadget terhadap Kemampuan Interaksi Sosial. Jurnal Obsesi: Jurnal Pendidikan Anak Usia Dini, 1(1), 1. https:// doi.org/10.31004/obsesi.v1i1.26

Puspita, W. A. (2010). Pendidik Pendidikan Anak Usia Dini (Paud) Sebagai Model Perilaku Anak Usia Dini. Jurnal Ilmiah Visi, 5(2), 209-215. https:// doi.org/10.21009/JIV.0502.9 
Putra, C. A. (2017). Pemanfaatan Teknologi Gadget Sebagai Media Pembelajaran. Bitnet: Jurnal Pendidikan Teknologi Informasi, 2(2), 1-10. https:// doi.org/10.33084/bitnet.v2i2.752

Rakhmawati, I. (2015). Peran Keluarga dalam Pengasuhan Anak. Jurnal Bimbingan Konseling Islam, 6(1), 1-18. https:/ / doi.org/10.21043/kr.v6i1.1037

Retno, A. (2013). Hubungan Intensitas Pendampingan Belajar Orang Tua dengan Kualitas Hasil Belajar Siswa di Ra Al-Islam Mangunsari 02 Semarang Tahun Pelajaran 2011/2012. Indonesian Journal of Early Childhood Education Studies, 2(2), 43-49. https://doi.org/10.15294/ijeces.v2i2.9240

Rohmah, E. Z. (2014). Manajemen Peserta Didik Anak Jalanan di Sanggar Alang-Alang Surabaya. UIN Sunan Ampel Surabaya.

Sari, T. N. (2020). Orang Tua Sebagai Organizing. Hasil Wawancara Pribadi.

Satgas Covid-19. (2021). Data Sebaran Pasien Positif Covid-19 di Indonesia.

Septiani, A. (2019). Peranan Guru Dalam Membangun Karakter Anak Usia Dini Melalui Metode Bercerita Di Taman Kanak-Kanak Sriwijaya Way Dadi Sukarame Bandar Lampung. UIN Raden Intan Lampung.

Siregar, N. S. S. (2013). Persepsi orang tua terhadap pentingnya pendidikan bagi anak. JPPUMA: Jurnal Ilmu Pemerintahan Dan Sosial Politik UMA (Journal of Governance and Political Social UMA), 1(1), 11-27.

Sisdiknas. (2003). Undang-undang Republik Indonesia Tentang Sistem Pendidikan Nasional Nomor 20 Tahun 2003.

Slameto. (2003). Belajar dan Faktor-Faktor Yang Mempengaruhinya. Rinek a Cipta.

Sudjana, D. (2004). Manajemen Program Pendidikan; Untuk Program Pendidikan Non Formal dan Pengembangan Sumber Daya Manusia. Falah Production.

Suharsimi, A. (2010). Prosedur Penelitian : Suatu Pendekatan Praktik (Edisi Revisi). In Rineka Cipta. https://doi.org/10.1017/CBO9781107415324.004

Sundari, F. (2017). Peran Guru Sebagai Pembelajar dalam Memotivasi Peserta Didik Usia SD.

Susilowati, S. (2019). Peran Orang Tua Dalam Literasi Dini.

Utami, M. T. (2020). Orang Tua Sebagai Modelling. Hasil Wawancara Pribadi.

Wahy, H. (2012). Keluarga Sebagai Basis Pendidikan Pertama dan Utama. Jurnal Ilmiah DIDAKTIKA, 12(2). https:// doi.org/10.22373/jid.v12i2.451

Wardani, A., \& Ayriza, Y. (2020). Analisis Kendala Orang Tua dalam Mendampingi Anak Belajar di Rumah Pada Masa Pandemi Covid-19. Jurnal Obsesi: Jurnal Pendidikan Anak Usia Dini, 5(1), 772. https://doi.org/10.31004/obsesi.v5i1.705

Wena, M. (2010). Strategi Pembelajaran Inovatif Kontemporer. PT. Bumi Aksara.

Winarsih. (2020). Orang Tua Berkomunikasi Dengan Pendidik.

Yanti, M. M., \& Rivaie, W. (2013). Kerjasama Guru Dan Orang Tua Guna Meningkatkan Hasil Belajar Sosiologi Siswa Kelas XI Di SMA Pontianak. Jurnal Pendidikan Dan Pembelajaran Khatulistiwa, 2(6).

Yanto, M., \& Syaripah, S. (2017). Penerapan Teori Sosial Dalam Menumbuhkan Akhlak Anak Kelas I Madrasah Ibtidaiyah Negeri 1 Rejang Lebong. TERAMPIL: Jurnal Pendidikan Dan Pembelajaran Dasar, 4(2), 65-85. https:// doi.org/10.29240/jpd.v1i1.221

Yulianingsih, W., Suhanadji, S., Nugroho, R., \& Mustakim, M. (2020). Keterlibatan Orangtua dalam Pendampingan Belajar Anak selama Masa Pandemi Covid-19. Jurnal Obsesi : Jurnal Pendidikan Anak Usia Dini, 5(2), 1138-1150. https://doi.org/10.31004/obsesi.v5i2.740

Yusuf, S. (2014). Psikologi Perkembangan Anak dan Remaja. Rosdakarya.

Zahrok, S., \& Suarmini, N. W. (2018). Peran Perempuan dalam Keluarga. IPTEK Journal of Proceedings Series, Vol. 3, No(5), 61. https:// doi.org/10.12962/j23546026.y2018i5.4422 